Vol. 3, No. 2, June 2021, pp. 124-132, doi.org/10.52567/pjsr.v3i02.213

www.pjsr.com.pk

\title{
THEMATIC ANALYSIS OF THE CONFLICT IN UNMARRIAGEABLE BY SONIAH KAMAL: A FORMALISTIC STUDY
}

\author{
Muhammad Zubair Iqbal \\ ORIC, National University of Modern Languages, Islamabad \\ drzubair.iqbal@gmail.com \\ Shafaq Kamal \\ Research Scholar, National University of Modern Languages, Islamabad \\ Qasim Shafiq \\ Assistant Professor, Institute of Southern Punjab, Multan \\ qasimmirzaa@gmail.com
}

\begin{abstract}
This study deals with the analysis of the novel Unmarriageable with reference to the (social) conflict by Soniah Kamal. The novel discusses important themes like materialism, feminism, marriages and fight against a conservative mindset etc. Thematically, the novel is very important because it deals with the conflictual aspect of present situation of Pakistani society regarding these important social issues. This is the time of advancement and liberty but the stereotypical families still force their children, especially girls to forced and unwanted marriages. This is one of the main problems that our young generation is facing. This research has been carried out using the qualitative paradigm and analysis of the text of the novel Unmarriageable. The study is limited to the analysis of themes with the help of theory of Formalism. This researcher has analyzed the novel and its main themes without going into the background, history or any personal information of the novelist because in Formalism it is all about the form, text, figures of speech, themes, cohesion, coherence and characters etc. The researcher analyzed and concluded that the writer used language, settings, characters and diction in a way that the novel disclosed and explicated these issues in influential and effective ways.
\end{abstract}

Keywords: Formalism, Snobbery, Stereotypes, Retrospection

\section{INTRODUCTION}

Literature is produced by the writers to reflect upon the problems we are facing in the real world. Those problems are presented by the characters, settings or themes of the piece of literature. People may focus on various aspects of their society's culture, language, history, faith, politics, traditions, attitudes, and beliefs through literature. Literature: either orally or in written form, helps us to transfer history, ideas, and facts about one generation to another generation. Literature provides the blueprint of a society or social system. Literature is not just cultural or historical artifact; it is way more than that. Language is the medium that is used by writers to convey their perception of the world. Usually, literature is written to magnify the historical, cultural or biographical aspects of a certain era or poet. These contexts can be used to analyze a text and figure out what the writer desires to say. However, the language itself can signify the intention of the author. The form and content of a certain novel or piece of poetry are enough to make a path for the understanding of it. Certain elements of the literature like symbols, metaphor, irony, etc. are the ways to analyze the form of the literature. This way the analyzed text stays far away from the external influence and we clearly get acquainted with the use of languages by the writer.

Novel is one of the most prominent and strong ways of teaching people life lessons by fictional characters and events. It is a long narrative prose fiction work and it tells the stories about 
human experiences. There are many characteristics of novel but fictional subject matter, prose style and considerable length are the most prominent characteristics. It is very different from long narrative epic poems. Novel consists of many characters, events and their details.

English has become an international language in past few decades. Many Pakistani writers have produced literature in English language. Ejaz Rehman, Harris Khalique, Zulfikar Ghose, Kamila Shamsie and Soniah Kamal are the most known literary figures in this field.

The novel Unmarriageable by Soniah Kamal is the retelling of the novel 'Pride and Prejudice' by Jane Austen. The novel "Unmarriageable" is written in the context of Pakistani culture. The setting of this novel is Lahore and Dilipabad which is a small town in Pakistan. It accentuates the problems of the traditional Pakistani society which we are facing even in the $21^{\text {st }}$ century. The selected text of the novel will be analyzed to figure out the themes and through themes, it will enlighten us with the social problem of Pakistani society. The protagonist of the novel is Alysba Binat who is a fierce character who never hides her dislike for the traditional rules of society like early marriages, hunt for a rich husband, class differences, arrange marriages etc. Many of the researches are conducted on the thematic analysis of different novels by different writers. For example, Mahari Negash directed research on thematic analysis of "The Old Man and the Sea" which highlighted the themes of victory, dignity, acceptance, and maturity. Bereket Lemma figured out the themes of colonial oppression, competition, disagreement, revenge, racism while analyzing Chinua Achebe's novel "Arrow of God". The researcher conducted research on the thematic analysis of Soniah Kamal's novel "Unmarriageable" which was written in 2019. The researcher analyzed the themes of the novel by using the literary theory of Formalism.

Literary theory of Formalism was developed in Russia and America but in literary circles, Russian Formalism was flourished. The Russian revolution has a great impact on Formalism. Theory of formalism analyzes the text of novel without going into the details of social history, circumstances, writer's point of view and her personal experiences. It directly examines the use of language, diction, literary devices, cohesion and coherence and structure. It will show that how the novelist uses language gather ideas and deliver her message and the importance of language in the delivery of message.

\section{Statement of the Problem}

The real essence of any literary text can be compromised if we read the text under any cultural, historical or biographical influences. The researcher tries to investigate this particular text without any external influences and solely focuses on the language of the text using a formalistic approach. This study finds the themes of the novel as there is no previous research on the thematic analysis of the novel Unmarriageable by Soniah Kamal. As a result, there is a void that needs to be filled, so the researcher decided to investigate this novel.

\section{Significance of the Study}

This study highlights some of the social issues which are normalized by society. Pakistanis are obsessed by the rotten traditions and rules of society. They have made up their minds that their culture would be ruined if they do not conform to these rules. The social expectations from woman of the society are that they have to get a wealthy, handsome husband and be married early. Women are supposed to be shy and be submissive while men can be arrogant and rude (Ter Maat, Truong \& Heylen, 2010).

When women attempt to defy these standards, they are met with hostility by society as they did with the protagonist of the novel. These are some of the problems which the researcher has tried to analyze through the novel with formalistic approach which will bring forward the importance of usage of language to convey the intended meaning. The novel Unmarriageable aims to show the rebellious side of woman in the character of the protagonist 'Alysba Binat'. This study provides an insight to the readers who are interested in the social issues of present Pakistan through the thematic analysis of the novel Unmarriageable by Soniah Kamal. Formalistic approach is important when we want to study a 
Iqbal, Kamal \& Shafiq

novel without any context. This research provides an insight into how author used language to highlight the themes of the novel. The sole focus of the study is how to analyze the use of language to figure out the themes of the novel Unmarriageable.

\section{Objectives of the Study}

The objective of this study is to:

1. To comprehend the themes of the novel "Unmarriageable".

\section{Research Questions}

This study attempts to answer the following question:

1. What are the various themes presented by Soniah Kamal in the novel "Unmarriageable?

\section{Delimitation}

Soniah Kamal, (2019) has written other significant literary works but the current study is limited to thematic analysis of only one of her novels Unmarriageable.

\section{REVIEW OF LITERATURE}

The formalist approach, Kennedy \& Gioia, (1995), regards literature as a specific type of human knowledge that must be analyzed on its own terms. All of the elements necessary for understanding the work are contained within the work itself; the elements of form style, structure, tone, and so on that are found within the text are of special interest for the formalist critic. For formalist critics, determining how such elements influence the text's content to shape the text's impact on readers is a primary objective.

One of the most striking characteristics of Russian Formalism is its unwavering confidence in the autonomy of literary science. They believed that literary science might and should exist independently of the reach of the outside world. First, the Russian Formalists aimed to have proper ways to engage with literature by recognizing the uniqueness of the category of texts that is called literature. They are mainly interested in analyzing formal aspects of literary texts with the special rules they are attempting to develop for literary review. The Formalists were interested in what made a work a literary art, i.e. the literariness of the work, so they focused on the literary type of literary works. Russian Formalism provided a meaningful framework for literary studies to counter the overpowering waves of then-dominant historicism and psychology, and established literariness as the utmost focus of literary criticism (Lee, 2018).

Theme is interpreted differently by various authors, but generally can be characterized as a literary works or story's main theme. The central idea and unifying principle of the tale, according to Melankneh, (2006), is described as theme. The theme, according to this description, is the focal point of the plot. It refers to the key concept that readers grasp after reading the entire story. The novel's theme is the truth about human life exposed by the occurrences in it, according to Anderson and Singley, (1989). The readers will notice or recognize that there is something in the story that affects human life based on this concept. Themes may be mentioned directly in the story by the author or inferred from the actions and conversations of the characters, with the readers deducing the implied context from the actions and conversations of the characters.

The setting, according to Melakneh, (2003) is the world, the physical time, and the location where the story takes place. The context, climate, or the world in which we live and travel as well as the physical characteristics of our surroundings, is all part of the setting. Setting, according to this definition, refers to the time, place, and physical characteristics of the plot. "In novels and short stories, the setting, the time and place in which characters are formed can also be crucially important, not implied that writers use it to communicate details about the mood or environment of the characters themselves, either symbolically or by adopting the characters' points of view against it" (p. 44). Gray, (1995) indicates that the writers should benefit from the setting to show the characters' tone, surroundings, premise, and sense of the story. Understanding these issues will assist the reader in determining the story's theme (p. 28). 
It's possible that characters will appear to highlight the theme. Kirszner \& Mandell, (2011) define characters as a fictional portrayal of a person that is typically (but not always) psychologically realistic. Any human, animal, or thing that performs any actions in the novel or story is considered a character. The literary work's themes can be discovered by their actions or some other actions. Melakneh, (2008) defines characters as those who are accountable for the thoughts and actions in a novel, poetry, or other work of writing. We can say that dialogues and acts of characters present themes of the novel because themes can be communicated by actions. According to Griffith, (2011) plot is described as the acts, statements, thoughts, and feelings that occur in the narrative. It refers to the events of the stories in general. According to these concepts, the plot encompasses all of the story's events, and the story's themes can be depicted by narrative events. According to Anderson et al. (1989) the story is comprised of a chain of interconnected events. We may deduce from this concept that the plot connects the story's events. The plot, according to Kirszner \& Mandell, (2011) is the arrangement of events in a story; it is formed by causal relations, historical, social, and personal, by character interaction, and by juxtapositions. From this description, we can deduce that the plot is a sequence of events that are connected in a causal manner to construct a story. According to Gordon and Kuchner (1992) as cited in Yaya \& Sayra, (2019) plot is the order in which events in a story are presented. It is the organizing principle that determines how events unfold. The reader will recognize the story's dominant concept based on the proper arrangement of the events and actions.

"Conflict is the struggle between opposing powers on which the action in a work of literature depends" (Melakneh, 2006, p. 206). Conflict, according to this definition, is any internal or external conflict between characters in a work of literature. It contributes to defining the theme, which ensures that when characters encounter the reader can discern the theme from the conflict's action.

According to Methewos, (1999) style refers to the qualities of how a certain writer employs the linguistic tools as the platform of all literature, which is fictitious poetry and drama in a language. It signifies that most authors can attain their work's core concept or significance by employing literary techniques such as symbolism, irony, and so on. "Style is how a writer chooses and arranges words to convey what he or she wants to say," say Kirszner \& Mandell, (2011). The writers may use their writing style to express what they intend to say or their key focus or theme, according to this concept. The writer's style can be read and understood by the reader. It is possible to write it in allegorical form.

In another article, the writer, Wang, (2016) explains the literary criticism and she also applied Formalism to Charles Dickens' novel "David Copperfield". Researcher referred to Percy's comments about analyzing novels with the help of the theory of formalism. According to Percy, literary criticism should take a more scientific and objective method. He also believes that criticism should not discuss the background of writer or author instead, new critics should focus on the "form, style, construction, and design" of the novel. In the researchers' opinion, the complexity of fiction writing skills, and perspective is crucial, Researcher pointed out that, "David Copperfield," is described in the firstperson narrative and that is not dramatic, but very natural in its form. The research also discussed the publication of Percy's "novel technique" to show that how we should criticize a novel. In modern ways, Percy's creative insight is to each check a variety of narrative perspectives in given texts. He said the novelist is impartial in criticizing novel rather we should focus on the form and characters in novel. Researcher further says that from the character's inner world or their form of portrayal, or one can put himself in the position of one of the characters, and the thoughts and motivations of the other characters pretend to know nothing about it or one can take a certain attitude ranged between these attitudes. Researcher also refers to "Edgar Dickens" and said that he did not appreciate the structural style of Dickens she believes that, "in terms of structure, Dickens is his own worst enemy" (Wang, 2016, p. 603), if he can have worked on self-criticism, he could be a more outstanding novelist. According to the researcher a good writer must not change the character of the hero and the characters in the novel based on the needs of readers. He concluded that Charles Dickens was most concerned about is in any case let his readers meet, rather than the form and structure of the novel.

Murray, (1999) explains the idea of Viktor Shklovsky also cited in van den Oever, (2010) that the "Art as technique". Shklovsky was one of the firsts who introduced the idea of Russian formalism 
Iqbal, Kamal \& Shafiq

and gave his statements about his idea of analyzing literature as a technique. For him, the form of literature and art are more important than the content. According to Murray, (1999) Shklovsky and his members of the group were against the traditional and old methods of criticizing and analyzing literature. This group of critics divided language into two parts, practical and poetic language. Murray, (1999) further says that for Russian formalists it was not important what was said rather how it was said. Murray, (1999) declares that the most important thing of formalism was the shifting of attention from old traditions of analyzing the work to the language and form of literature.

\section{RESEARCH METHODOLOGY}

The research is descriptive in nature and it was carried out via a qualitative approach. The research is conducted on the novel, Unmarriageable by Soniah Kamal. The researcher analyzed the text of the novel through content analysis with the help of a formalistic approach as a theoretical framework, to take out the themes of the novel.

\section{THEORETICAL FRAMEWORK}

The idea of Formalism developed in America and Russia but Russian formalism flourished in literary circles and among the literary critics. It began in two groups, it was led by Viktor Shklovsky in the society of poetic language, and in the Linguistic circle of Moscow, and it was led by Osip Brik, Boris Tomashevsky, Boris Eikhenbaum and Yury Tynianov. Formalism in Russia flourished before and after the Russian revolution. It had a strong effect on the literary criticism of that time period. Basically, formalism was a reaction against the romantic theory and ideas of literature. From the name of the theory "Formalism," it is clear that it deals with the form of a text. Formalism includes language, literary devices, tone, structure of a text and its organization. It also includes words (meanings), the harmony of the words, the rhythm of the sentences, the rhyming of the words and the meaning of the text as a whole. It excludes the biographical, historical, social and intellectual contexts of a literary text. It also excludes time period, background, author's political, moral and religious ideas and his personal life. There are different thoughts by critics to describe Formalism. It is not literature itself but a phenomenon in literary texts as Jakobson (1919) called it "Literaturnost". He stated that,

"It is literaturnost that makes a given work a literary work".

It means that a work is literary when it is analyzed through its artistic techniques and other literary devices. Shklovsky, (1917) also cited by Ayers (2011), a prominent Russian critical and literary figure stated "Art as technique". It means that an artistic or literary piece is only artistic when it is analyzed technically and in formalism, art is analyzed through literary techniques. "Theory of Formalism" focuses on a deep understanding of words sentences and their meaning collectively and individually. It says that a text can be understood through the form and language used in the text. The researcher has analyzed the text through the characters, setting and connectedness of the text. Figurative language like consonance and imagery has been used by the writer to make clear some of the themes of the novel. Yury Nikolaevich Tynyanov, also cited in Gorman, (1992) and joseph, (1994), Soviet writer and literary critic also gave his view about literary criticism. According to him, "Literature must be studied as a system. All evidence, whether literary or non-literary must be analyzed functionally".

Unmarriageable by Soniah Kamal has not been analyzed yet through the lens of the theory of formalism. In this research, the researcher formed a theoretical framework with the help of the theory of formalism and Formalistic thoughts shared by global critics and scholars. The novel Unmarriageable is a Pakistani version of Austen's Pride and Prejudice.

\section{DATA ANALYSIS AND DISCUSSION}

A literary piece is written to convey a message to the readers. This message may be delivered through symbols, characters, settings, or images used in the literary text. Themes are the crust of the novel. Readers figure out the themes to know what the writers try to say in their works. Themes usually have social, historical, and cultural context, however, we can also figure out themes by solely depending on 
the characters or the words uttered by the characters without any context. By applying formalistic approach to the elements of the novel, we are able to highlight the themes. Formalism is an approach that says that we can analyze a text depending on how the work is organized, the point of view of the narrator, literary devices such as imagery, symbols, metaphors etc., the characters, and the cohesion or connectedness of the text. All these elements work together to create a piece of text which contains themes of the text. The individuality that a person possesses is ignored because we form opinions about people that may or may not be true. As we see in the novel Unmarriageable that the idea about girl being betrothed is quite generalized. It says:

"It is a truth universally acknowledged that a girl can go from pauper to princess or

princess to pauper in the mere seconds it takes for her to accept a proposal." (p. 3)

This sentence was uttered by one of the students of the protagonist "Alysba Binat" when she asked her students to recreate the opening sentence of the novel Pride and Prejudice by Jane Austen. We can get a hold of the society in which the novel is set, without considering the context and relying on the language, through this sentence. The imagery of the 'princess' is used here by the writer to emphasize the importance which is given to the engaged women. Usually, the treatment that is given to princesses is very royal and regal. We see that the writer is trying to portray the stance of society on girls accepting a proposal and getting high status in their community. It means that a girl is of no value when she does not have an acceptable proposal and an updated relationship status results in upgrading her social status as well. The stereotyped thinking that a woman can only be successful when she is engaged is infiltrated in the mind of every teenage or grown woman in society. We get to see the real representation of this above-mentioned stance when a student named Tahira enters the class and shows her four-carat diamond ring to her friends and in return gets princess-like treatment from them (pp. 67). The society acknowledges the fact that woman needs to get a suitable proposal to stand out in the society. In other words, women can only be appreciated when they have a suitor who is ready to marry them. With the help of only one imagery, we are able to decipher the theme of the Stereotypical mindset which tells us that we can depend solely on the formalistic approach to analyze a piece of text. The writer has used the consonance sound of ' $p$ ' in the words 'proposal, pauper and princess' to make the reader pay more attention to these words and language that she has used. This technique is used in formalism to emphasize more on the language.

Stereotypes result in social distinction, which is one of the causes of discriminatory practices (i.e., the "them" and "us" mentality), which results in in-groups and out-groups. We see that Darsee's opinion of Alysba was that she is a gold digger and reads book to impress men because at Dilipabad all he knew was that girls wanted to catch the attention of rich men around them. Later when he proposed to Alysba at her uncle's house, he said:

"In fact, it's a disadvantageous match for me in all respects ---well except that you're smart, fun, have a quirky personal style, which I like. And you are not a gold digger." (p. 239)

The cohesion and the choice of conjunctions in the above sentence tell us a lot about Darsee's perception of Alysba and also about Darsee's state of mind. Text unity is the cohesiveness of a literary work that is found in abundance over here. It points to the choice of words that relate one element to another in the text. The above mentioned sentence is enough to tell us that Darsee stereotyped Alysba and formed his perception of her that she is like other girls who are gold diggers. It is because of her mother and sisters' unmindful behavior that Darsee has the worst opinion about the Binat family. He visited Dilipabad and was annoyed by the circumstances he faced there. He made his perception that all the women at Dilipabad have the same mental caliber. Like all the other girls, Alysba is also trying to get his attention by posing that she is not attracted to him. But we know that Alysba wasn't trying to get his attention and that she despises him. When the story moves towards its end, he accepted his prejudice against her and proposed to her. Darsee is excited and overwhelmed to propose to her. So, while analyzing the mentioned sentence, we do not need the historical or biographical or social context of the novel as said by the formalistic approach to reading text. A stereotype is an unchanging, overly generalized belief about a specific group of people. So by concluding the above discussion we can say 
Iqbal, Kamal \& Shafiq

that the novel "Unmarriageable" possesses the theme of 'Stereotypical mindset'. Many instances in the text lead us to the situation where the protagonist Alysba is thinking about the past which was cheery and full of joys (pp. $20-27$ ). A person usually contemplates the happy memories of the past because those joyful moments have been absent in their present life. We see that previously the life that Binat family spent in Jeddah.

"The Binats resided in an upscale expat residential compound, which had a swimming pool and a bowling alley, and Pinkie hired help. "( $p .23)$

The above-mentioned sentence clearly states that the lifestyle of the Binats was more luxurious than the one they have in Dilipabad. The phrase 'upscale expat' tells us that they are enjoying their time abroad. Even though they are displaced from their native land to work in Saudi Arabia, they are pleased with the exclusive lifestyle they are living. The use of past tense tells us that the protagonist is reminiscing about her past life. Life in Jeddah was comfortable; they had friends, high class schools, and no financial worries. Their house had a swimming pool and a bowling alley (p. 23). These are the luxuries that can only be available at lavish houses. It means that their life was filled with magnificence and now that they are in Dilipabad, they only think about their past and lament on it. As mentioned by Russian formalists, we can say that text can be analyzed with the help of text only.

"It took her back to a time when their mother would dress her and Jena in frilly frocks, a time before their father and his elder brother, Uncle Goga, were estranged, a time when they'd been one big happy joint family living in the colossal ancestral house in the best part of Lahore: her paternal grandparents, her parents and sisters, Uncle Goga, Aunty Tinkle and their four children" (p. 20)

Again, we can note the cohesiveness through which the writer has showed a connection between her mother dressing her in frilly frocks and all of them living in a happy joint family at their ancestral house. Through the cohesive nature of this long sentence, we can figure out Alysba's longing for these things. It tells that she longs for the connectedness and relations she had in the past. Long sentences are usually written to show that the character is in deep thought and thinking about something of grave nature. The seriousness is shown here because the protagonist is leading a life that is filled with struggle and a lack of warmth. When they were in Lahore, they were living a comfortable life and with their kin. Now, when they are financially unstable, they have no support from their relatives and hence, lack of love and connection. The form of this sentence clearly states her yearning for her old luxurious home, her uncle's family and her paternal grandparents. In Dilipabad, they hardly have friends to share their lives with and enjoy themselves. They miss the time when they were pampered by their family, now they have to act like grownups and work hard to pay their bills and earn bread and butter for the family. The financial situation has left everyone wondering about their futures especially Mrs Binat, who is always worried about marrying off her daughters. Retrospection is an act of looking at the events that happened in the past. This situation justifies Alysba's retrospection about the past which had peace and affection towards each other. We can confidently say that by analyzing the form of the text of 'Unmarriageable' we can take out the theme of retrospection. This is the approach that formalists take a stand of.

People usually show snobbish attitudes because they want to make others feel low about themselves. This case can be seen in the novel Unmarriageable, many of the characters are suffering from arrogance because of their wealth. They think that they are superior to others just because they spent their vacations abroad, can speak English and wear designer dresses. The Bungles sisters, hammy and Sammy can be often seen to ridicule Binat family for their financial problems and Darsee's aunt Beena Dey Bagh's attitude towards Alysba is evidence of how much pompous these characters are. An excerpt from the novel can tell a lot about this theme. When Beena Dey Bagh inquired Alysba about being engaged to Darsee, she said:

"A place where you should not be able to open your mouth in front of me, let alone

dream of being engaged to a Dey Bagh. Who are you? Nothing and no one." (p. 310)

The above mentioned dialogue by Beena Dey Bagh tells us a lot about her attitude towards other classes of society. Through Beena Dey Bagh's character, we can analyze the snobbery shown in 
the novel. She thinks highly of herself and mistreats others because she has financial stability. She knows that Alysba's social status is not as high as hers so Alysba can't marry Mr. Darsee. The strong financial status is so important to her that she thinks of Alysba as nothing in front of her and insults her. She cannot tolerate any breach in social rank because she thinks that the lower class has nothing to do with the higher class and they will stain their family name. Money is so important to her that she does not feel bad in treating others as someone of no respect and dignity. As in the above-mentioned sentence, she is treating Alysba as someone with no self-respect and she continues to insult her. Just because Alysba does not have financial stability as hers, Beena Dey Bagh considers her as someone who cannot take a stand for herself in front of her. If one does not have a strong social background, they have no right to get engaged to a person from a higher class. So again we come to the conclusion that through the language used by the writer we can figure out themes of the text (p. 310). This contempt can also be seen in the attitudes of the Bungles sisters; Hammy and Sammy whenever they talk about the Binats. They don't think of Jena able to marry their brother because her social status

does not match theirs. When Jena was in the hospital, Hammy's scorn was one way to show that she hated the Binat family and how much financial status means for them.

Hammy said. "The Binats lived in Saudi Arabia for a while, where they attended, I

believe, the Pakistan Embassy School". (p. 113)

Hammy mocks that the Binats lived in Saudi Arabia and also says they must have attended Pakistani Embassy School there. It is because she thinks that Binats have always been poor and even in Saudi Arabia they wouldn't be able to attend an international school. In her prejudice, she didn't see how much able Alysba is and how kind Jena is. The difference in social status between them does not let her break her pride. So, from the characters of Beena Dey Bagh and Hammay, we can say that novel "Unmarriageable" holds the theme of class difference and snobbery. Again, this was idea given by formalism that we can analyze the text through the characters of the novel. Marriage is a lifelong commitment between two people who pledge to stay with each other through thick and thin. This commitment should be based on love instead of security. In the novel, we see different ideas relating to marriage which tells us that people get married for gaining financial stability. A student while recreating the opening sentence of Pride and Prejudice wrote:

"It is a truth universally acknowledged that if you are the daughter of rich and generous parents, then you have the luxury to not get married just for security." ( $p$. 5)

The form and language of the sentence clearly tell us that it has been happening that girls get married for financial security. The writer calls it a 'luxury' to get married for love otherwise we see that Sherry gets married to gain financial security and not love. We see that in the novel Unmarriageable, the protagonist Alysba is forced to marry Farhat Kaleen by her mother but she refuses to marry just for the sake of his high financial condition. She wants to get married because of love. Alysba refuses to consider her financial and social background before marrying anyone. She is of the view that one should marry solely because of love. We see that as soon as Farhat Kaleen proposes to Sherry she accepts the proposal and decides to marry him. She does not love him still she agrees because this marriage could provide her security. Alsyba and Jena, on the other hand, decline the truth universally acknowledged and marries Darsee and Bungles, respectively, because of love. Hence, we can say that the form and language of the text helped us to understand the novel and figure out the themes with the help of cohesion, characters, and figurative language used by the writer.

\section{CONCLUSION}

The idea of conflict in the social contexts is the description of Pakistani society as to how the social system deals with the sensitive issue of choosing partners and marriage. Theme is the main point of any literary work. Themes can be found in the novel or poem by investigating the characters, setting, dialogues, and language used by the author, as done in this research. Different themes of the novel such as stereotypical and conservative mindsets, materialistic approach, snobbery, and marriage have been discussed to make a meaningful conclusion. The novel is based on Pakistani society; thus, we can 
Iqbal, Kamal \& Shafiq

say after the analysis of the excerpts that most of the social conflicts exist in the Pakistani society. Though the novel has been analyzed through formalism, the authors have mentioned in the novel that its setting is Pakistan. The researchers have analyzed these themes with the help of the theory of formalism. The novel is very much sensitive in its nature and it is very important for our society to understand multiple issues related to gender, language and education. The researchers concluded that the themes and storyline of the novel are very significant and considerable that the novel can stand out alone without the above-mentioned aspects. There are many literary works on such topics but it is the diction and use of language by the author that makes it significant and influential. Soniah Kamal used language in a way that every action and event depicts the main themes of the novel. Kamal has disclosed that how common families find and choose partners for their children especially for daughters and what one can face if go against these conventional norms. The novel also exposed the hypocritical face of our society that boys can find their spouse on their own and they have complete freedom but girls cannot do the same. They have been forcefully restricted to do this and accept whatever their families imposed on them.

To sum up, Kamal has raised a very important and present issue by using very powerful themes, characters, imageries, ironies and characters and conveyed her message. A better understanding of the novel can change the conservative thinking and action of the reader. Novel Unmarriageable is way open for researchers and scholars in many aspects to work and make different conclusions according to their approaches.

\section{REFERENCES}

Ayers, D. (2011). 'John Cournos and the Politics of Russian Literature in The Criterion'. Modernism/modernity, 18(2), 355-369.

Devika, S., (2016). Russian Formalism. Retrieved from:

https://drdevika.wordpress.com/2017/04/19/russian-formalism-2/

Gordon and Kuchner (1992). An Introduction to the Short Story London: Contemporary Publishing Inc.

Gorman, D. (1992). A bibliography of Russian formalism in English. Style, 554-576.

Griffith, K. (2011) Writing Essays about Literature, a Guide and Style Sheet (8th ed) Canada Michel Rosenberg.

Joseph, L. P. (1994). From literary theory to fiction: An interpretive biography of Yury Tynyanov in the 1920s (Doctoral dissertation, Stanford University).

Jacobson, C. A. (1919). ALFALFA SAPONIN. ALFALFA INVESTIGATION VII. Journal of the American Chemical Society, 41(4), 640-648.

Kennedy, X, J. \& Dana G.(1995) Literature: an Introduction to Fiction, Poetry and Drama(6thed) New York Harper Collins Kirszner, L. G., \& Mandell, S. R. (2012). Literature: Reading, reacting, writing. Wadsworth Cengage Learning.

Lee, J. J. (2018). RUSSIAN FORMALISM AND ITS LEGACY.

Laurie, G. Kirszner and Stephen, R. Mandell (2011) Literature Reading, Reacting Writing (4th ed): USA Earl Mc.

Melakneh M. (2008). Fundamentals of Literature (4th ed): Addis Ababa University Press

Melakneh M., (2006). Fundamentals of Literature Addis Ababa Bole Printing Press

Melakneh, M. (2003). Fundamentals of Literature for Colleges.

Methewos, B., (2009). Fundamentals of Literature Addis Ababa Alpha Printing Press

Murray P. R. (1999), Art as Technique: Viktor Shklovsky and Russian Formalism.

Shklovsky, V. (1917). Art as technique. Literary theory: An anthology, 3.

Singley, M. K., \& Anderson, J. R. (1989). The transfer of cognitive skill (No. 9). Harvard University Press.

Ter Maat, M., Truong, K. P., \& Heylen, D. (2010, September). How turn-taking strategies influence users' impressions of an agent. In International Conference on Intelligent Virtual Agents (pp. 441-453). Springer, Berlin, Heidelberg. 
Yaya, E., \& Sayra, Z. (2019). Thematic Analysis of Solomon Hailemariam's Novel entitled 'The Young Crusader'.

van den Oever, A. (Ed.). (2010). Ostrannenie: On" strangeness" and the Moving Image: The History, Reception, and Relevance of a Concept (Vol. 1). Amsterdam University Press.

Wang, L. (2016). Research on Formalism and New Criticism of Dickens' Novels. 